\title{
Protecting Boat People REPLY TO JAMES BisSETT
}

\author{
David Matas
}

$\mathrm{J}$ ames Bissett cites the country operation profile on Sri Lanka of the Office of the United Nations High Commissioner for Refugees (UNHCR) and suggests that does not support my assessment of the human rights situation in Sri Lanka. That profile though is not an assessment of the human rights situation in Sri Lanka, but rather of the working environment for those assisting the internally displaced and voluntary returnees.

The UNHCR is an intergovernmental agency operating within Sri Lanka with the permission of the Government of Sri Lanka. Its operational constraints prevent it from making the clearcut statements about the human rights situation in Sri Lanka that non-governmental organizations operating outside of Sri Lanka are free to make.

Amnesty International USA on its website about Sri Lanka, the Minority Rights Group, in a report published in January 2011 "No war, no peace: the denial of minority rights and justice in Sri Lanka", and The International Crisis Group, in a report titled "Sri Lanka's North I: The Denial of Minority Rights" released in March of this year paint a much more detailed picture. They report disappearances, torture, detention without charge or trial, attacks on journalists and human rights defenders, violent crackdown on protests, extrajudicial punishments, intimidation and harassment, including sexual harassment and rape at the hands of the military, as well as impunity for perpetrators.

All this is done in an atmosphere of creeping Sinhalization, the denial of cultural, religious, and linguistic rights of the Tamil minority. The North and East remain under military occupation. Tamils displaced by the conflict are not allowed to return nor reclaim their properties. The UNHCR in its country profile notes this last problem and states politely "This complex situation requires adequate measures by the Government if it is to be resolved."

Mr. Bissett also refers to a UNHCR statement supporting Canada's handling of the arrival of the Sri Lankan Tamils aboard the Sun Sea. This reference is selective, ignoring UNHCR concerns about Canadian government legislative proposals for mandatory detention, multi-year detention and weakened processing prompted by this arrival ${ }^{1}$.

Mr. Bissett is not clear why I referred to the Comprehensive Plan of Action. The reason is the need for an agreement between countries of traditional resettlement and countries of proximate refuge to prevent mistreatment by countries of proximate refuge.

At the time of the Comprehensive Plan of Action, the mistreatment was acute, including pushbacks-refusal to allow Vietnamese boat people to land. While thankfully today countries in the region will allow asylum seekers to land, they are treated, once landed, so poorly they make every effort to leave. There is as much a need for a regional agreement now as then.

The details of the Comprehensive Plan of Action no longer serve as a model, since resettlement in the region shou ${ }^{2}$ ld be a possibility. The concept of the Comprehensive Plan of Action, though, an agreement between countries of proximate refuge and countries of traditional resettlement should serve as a model.

Mr. Bissett suggests that the UNHCR is opposed to the sort of regional agreement I have proposed. Yet that is not so. The UNHCR has made no statement on the subject. The Government of Canada has, as the original article notes, in favour of such a regional agreement. The trouble though is that there is no visible indication that the Government of Canada has done anything concrete to follow up that policy statement.

The Refugee Convention limits the refugee definition to fear. A Convention refugee is a person with a well founded fear of persecution. When it comes to addressing the root causes of flight though, lessening the basis for fear is not sufficient. Asylum seekers are motivated both by fear and hope, fear at home and hope for better abroad. 
Since the civil war in Sri Lanka ended the basis for fear has abated, though far from ended. Regrettably, the basis for hope has also lessened.

As long as the civil war continued, the Tamil minority population had some hope that through victory, a negotiated settlement, or even a continuation of the one time existing cease fire, respect for their minority rights would be realized. The end of the civil war in Sri Lanka, coupled with a victor who shows not an ounce of magnanimity, offers immunity to the perpetrators, denies the victimization, and ratchets up minority oppression has meant for the Tamil minority of Sri Lanka an end of hope.

There are now more Sri Lankan Tamils outside of Sri Lanka than inside. Unless an effort at reconciliation is made, this diaspora will only increase.

More generally, to impact on asylum seeker flows, including the use of smugglers, it is not sufficient to address only fears, but also hopes, the hope that at home the situation will improve, as well as the hope for acceptance in countries of proximate refugee. Making the smuggled miserable in Canada addresses directly neither these hopes nor fears since, in spite of the enforced misery in Canada, hope, at the end of all that misery, for a better life in Canada remains.
All the while hope at home remains dashed and hope in countries of proximate refugee is never born.

Mr. Bissett suggests that I fail to recognize that human smuggling has become a serious international problem. However, one must not confuse means with ends. I certainly reject the solution the Government of Canada has proposed through first Bill C-49 in the fortieth Parliament and then Bill C-4 and Bill C-31 in the forty first Parliament, even in its most recently amended form, as an effective means to end smuggling. The rejection of that means is though not a rejection of the objective of combative smuggling. What the article I wrote attempts to do is instead proposed a more comprehensive solution to the curse of smuggling.

\section{Notes}

1. See UNHCR Submission on Bill C 31 Protecting Canada's Immigration System Act May 2012 reflecting and updating earlier concerns with earlier versions of the legislation.

David Matas is an immigration, refugee and international human rights lawyer based in Winnipeg. 